\title{
An Innovative and Applied Study Based on Behavior for Accidents Statistical Indexes in China Construction Project
}

\author{
Da-Wei CHEN ${ }^{1, a,{ }^{*}}$, Zhe $\mathrm{Ll}^{2, \mathrm{~b}}$, Ding $\mathrm{LI}^{3, \mathrm{c}}$ \\ ${ }^{1,2}$ School of Safety \& Environmental Engineering, Capital University of Economic \& Business, \\ Beijing, China \\ ${ }^{3}$ School of Resource and Safety, China University of Mining \& Technology (Beijing), Beijing, China \\ achendawei@cueb.edu.cn, ${ }^{\mathrm{b}}$ lizhesept@163.com \\ *Corresponding author
}

Key words: Construction accident, Safety behavior index (SBI), Safety management index (SMI), Accident statistical index, Behavior cause.

\begin{abstract}
The present accident statistical index for construction project only reflects the total number of accidents and fails to reflect the usual construction project safety and the weakness. Based on major accident cause of behavior and " $4 \mathrm{M}$ ", the framework was established for the causes of construction accidents including two pre-indexes, SBI and SMI, which the field of accidents statistics was enlarged. Combined with the existing construction accidents indexes, the new system was build up for construction accidents index including injuries rates and death rates by SBI and SMI. Besides the new system was applied one construction project and the result showed that this new index system reveals the weakness and the reality including usual safety management level of construction company.
\end{abstract}

\section{Introduction}

Construction industry is the pillar industry of national economy in China, developed rapidly in recent years, but the problem of construction safety production is becoming more and more serious. In 2012 the death toll of construction accidents is 2437 in China [1]. It is the first time their death toll surpasses all others such as coal industry. The scientific principle and accident prevention theory of safety production indicate that the accident frequency and rules based on the statistics is the most basic quantitative research method of safety science [2]. And the method is the scientific basis of accident preventive measures. Most industrial accident statistical index of developed country has more real data resources and wider range of casualty than of China, and pay more attention to the characteristics such as the pre-indexes $[3,4]$. At present the accident statistic of many industries including construction is based mainly on the objective results from serious accident consequences in China, but the ordinary accidents are not reported. So the number of fatal accident is much more than injure accident and the accident statistic data is not true [5,6]. The production safety level is barely analyzed and evaluated by the defective accident statistical index. It causes the working policy of "safety first, prevention prime, comprehensive administration" could hardly be implemented. Through explored the "pre-index" of construction accident, we expanded the range of accident statistical index and moved the statistic point forward. And we combined the existing accident index of construction project to build a index to real reflect the level of construction safety conduction. So the index could guide the routine safety management of enterprises.

\section{Accident statistical indexes in China construction project at present}

In recent years, accident statistical index is improved a lot in China. The national index of safety production control is composed of four kinds and 31 indexes[7]. The construction casualty statistics 
analyses mainly include the index of accident, death toll and death rate of ten billion output value at present. These accident statistical indexes objectively could only reflect the total number of fatal accidents, not the situation of severe injury, minor injury or violation in the process of daily production. So the indexes can not truly reflect the overall situation and level of construction safety and exist big limitations. And according to the Heinrich's law, numerous accidents inevitably lead to casualties and no injure accident (violation accident) have to be decreased and eliminated to prevent severe accident. Because the "no injure accident" means a lot of unsafe factors such as violation and risk may exist and just no injure temporarily. Therefore the present indexes can not reflect the whole safety situation of construction safety system and could hardly reveal the real weak link of production.

\section{Analysis of construction safety accident causes}

\section{Analysis framework of construction production safety accident cause}

Based on the research result of Heinrich [2], Frank E Bird Jr [8] and "4M" (Man, Machine, Media, Management) theory, we indicated the accident chain reaction as five linking different factors. These causal factors are injure, accident, immediate cause, underlying cause and basic cause. Based on the characteristics of construction industry and the analysis of basic cause, underlying cause and immediate cause, these three causes was reduced to two classes of construction sit and business management. The causes of construction site mainly consist mainly of the unsafe behaviors of human and unsafe state which easily cause accident. And the causes of business management are the management that hidden behind the first-line work and influence it. This is the Analysis framework of accident cause, as shown in the Fig. 1.

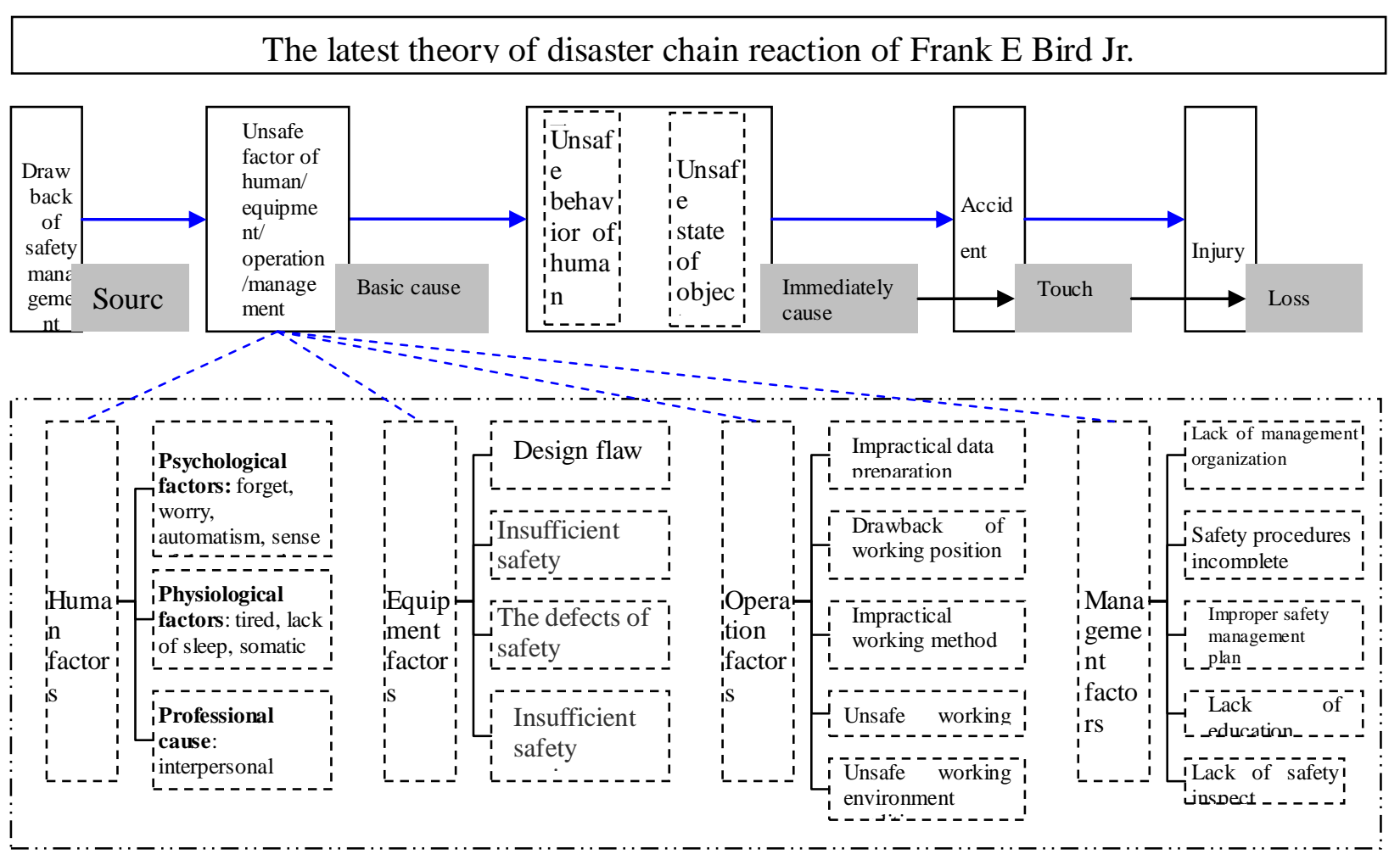

4M (Man/Machine/Media/Management)

Fig.1 Analysis framework of construction production safety accident cause

\section{Analysis of construction site causes}

The data, used in this paper, are 84 serious accident ( 3 deaths or above once) of building and 
municipal project happened through 2006 to 2008 in China. The cause analysis and expert comment of each accident was quoted [9]. According to the data and case, the construction site causes were confirmed by the analysis framework of accident cause. The causes are operation factor and equipment factor which cause $80 \%$ accident. And the rest of accidents are caused by management factor.

Therefore the construction site cause could be reduces to: (1)violation of operation rules or labor discipline; (2lack of safety equipment or failure; (3)unsafe production environment; (4lack of PPE or flaw; (5)technology or design defectiveness; (6)equipment, facility or tool defectiveness

According to analysis, above $80 \%$ accidents are caused immediately or indirectly by the unsafe behavior of human. So the unsafe behavior of human is the major cause of construction site accident.

\section{Analysis of enterprise management causes}

According to the " $4 \mathrm{M}$ " analytical method and the interviews of construction expert, there are five causes of management class. They including: (1)senior or midlevel manager don't pay enough attention to safety; (2)relevant system, regulation and plan incomplete or impracticable; (3)lack of safety check and meeting; (4)impractical safety education; (5)lack of safety investment.

Table 1 Proportion based on construction production safety accident cause

\begin{tabular}{|c|c|c|c|}
\hline $\begin{array}{c}\text { Classification of " } 4 \mathrm{M} \text { " } \\
\text { cause }\end{array}$ & Accident cause & Frequency & $\begin{array}{l}\text { Percentage } \\
\qquad 1 \%\end{array}$ \\
\hline \multirow[t]{2}{*}{ Operation factors } & $\begin{array}{c}\text { Violation of operation rules or labor } \\
\text { discipline }\end{array}$ & 59 & \multirow[t]{2}{*}{58.87} \\
\hline & Unsafe production environment & 14 & \\
\hline \multirow{4}{*}{ Equipment factors } & Lack of safety equipment or failure & 18 & \multirow{4}{*}{20.97} \\
\hline & Lack of PPE or flaw & 3 & \\
\hline & $\begin{array}{l}\text { Equipment, facility or tool } \\
\text { defectiveness }\end{array}$ & 2 & \\
\hline & Technology or design defectiveness & 3 & \\
\hline \multirow{4}{*}{ Management factors } & $\begin{array}{l}\text { Lack of safe operation rules or } \\
\text { incomplete }\end{array}$ & 5 & \multirow{4}{*}{19.35} \\
\hline & $\begin{array}{c}\text { Lack of safety education and } \\
\text { knowledge }\end{array}$ & 8 & \\
\hline & Lack of on-site check or misdirection & 8 & \\
\hline & Unreasonable labor organization & 3 & \\
\hline Others & Others & 1 & 0.81 \\
\hline
\end{tabular}

\section{Establishment of accident statistical index of construction production safety}

\section{Thought of establishment of accident statistical index}

The statistical point of accident statistical index is moved forward to emphasize the "pre-index" of accident statistical index of construction production safety. The pre-index aim at enterprise daily management is established. It finds out the index really reflect the safety condition of two classes of construction site and enterprise management. And then the level of enterprise safety is reflected from the perspective of "beforehand". After that, we combine the pre-index of two classes with the existing "post-index" like death rate and establish the new accident statistical index of construction production safety, as shown in the Fig. 2. 


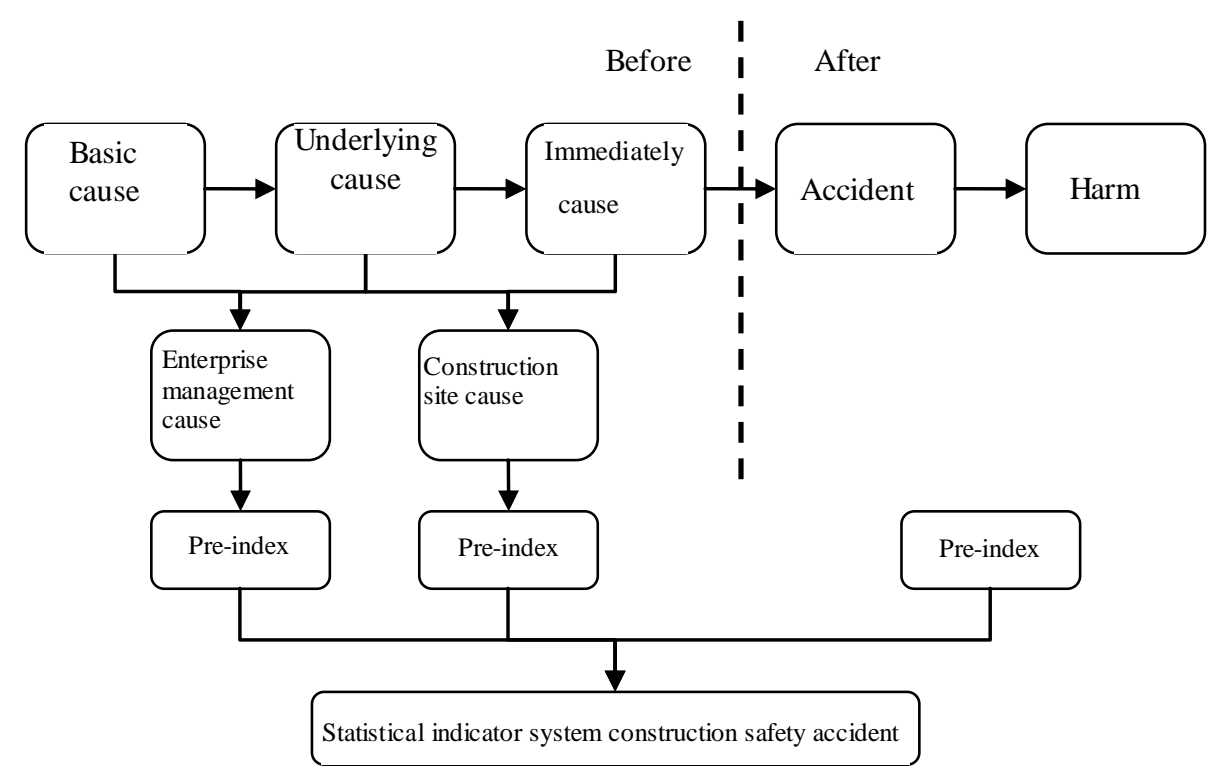

Fig.2 Statistical index system of construction safety accident

\section{Index of construction site}

Determination of construction site index. Through the accident cause analysis of construction site, above $85 \%$ accidents are caused immediately or indirectly by the unsafe behavior of human. Therefore the unsafe behavior of human is the mainly and root accident cause on construction site. We establish the SBI ( Safety Behavior Index)[4] to quantify the unsafe behavior of human, e.g.

$$
S=\frac{N_{2}}{N_{1}+N_{2}} * 100 \%
$$

$\mathrm{N}_{1}$ is the observed number of unsafe behaviors; $\mathrm{N}_{2}$ is the observed number of safe behaviors, $\mathrm{N}_{1}+\mathrm{N}_{2}$ is the total observed number of behaviors. $\mathrm{S}$ is SBI, means the proportion of safe behaviors to total behaviors. Through the $\mathrm{S}$, a rough idea of behavior safety status of an individual or a department or post would be got. Because the unsafe behavior present before the accident, we can monitor $S$ to prevent accident. When $S$ decreases, we can take steps to control the accident before it happens. So SBI is the pre-index.

Determination of key behavior. Key behavior is the unsafe behavior easily cause accident. To recognize the unsafe behavior, we mainly take the follow ways: (1) Past accidents statistical analysis and test enterprise accident report; (2)"three violations" records, the construction site safety inspection and safety audit results; (3) safety rules, operating procedures, management system and measures; (4) consult the safety managers and technicians, ask for the first-line job foremen and works; (5) all kinds of related documents and information.

According to the above work, we conclude four kinds of observable unsafe behavior that is suitable for construction[10-13], as shown in the table 2. The first three kinds of key behaviors are common unsafe behaviors on construction sites. They reflect the universality of SMI. The third kind of key behavior needs to combine with the specific job of practical application. It reflects the particularity of the index.

Measuring method of SBI. During concrete operation, the different kinds of operation of dangerous sub-project should be classificatory measured with practice (e.g. lifting operation, excavation). We observed every worker's behavior according to the SMI key behavior observation, and after a round of the observation we got the original data of SBI in that kind of job. The data 
could work out the number of worker's safe and unsafe behavior and then work out the total number of safe and unsafe behavior in that kind of job. According to the formula of SBI we can figure out the SBI of that kind of job.

Table 2 Key behavior in construction safety accident

\begin{tabular}{|c|c|}
\hline Category & Key behavior \\
\hline Individual protection & Lack of head/face/eye/ear/breathe/hand/foot/fall/body protection \\
\hline Tool and equipment & $\begin{array}{c}\text { Tool and equipment is not suitable for the operation. Improper usage. } \\
\text { Badness equipment I }\end{array}$ \\
\hline Personal location & $\begin{array}{c}\text { Unsafe place of worker(may be collide, clamp, fall, hit, trip and } \\
\text { electric shock) }\end{array}$ \\
\hline Operation program & Violation of operational program \\
\hline
\end{tabular}

\section{Index of enterprise management}

Determination of enterprise management index. The causes of enterprise management can not measure immediately, so we use the method of safety climate diagnose. The method is indirectly measure the safety status of enterprise management with some index to reflect the safety level of the enterprise[14]. The major way of the safety climate diagnose is apply safety climate questionnaire to quantitatively measure the safety culture and safety management level of the enterprise [15]. The safety climate questionnaire method is a kind of questionnaire method essentially. The key of the method is confirm the key factors and design specific questions according to the factors. The total level of the key factors reflect a kind of safety level of the study object.

Therefore we used SMI as the statistical index of the enterprise management of construction production safety accident. The SMI table was designed refer to the method of safety climate questionnaire. According to the table we got SMI to quantitatively evaluate the safety level of enterprise management.

SMI table design. The purpose of the table is get the SMI statistical index by evaluate the factors of accident causes of enterprise management. Therefore we combined the problems and causes of enterprise safety management with key factor method of the mature safety climate questionnaire to propose five key factors of SMI table (see table 3).

Table 3 Contrast of key factor of construction safety accident in enterprise management level

\begin{tabular}{|c|c|c|}
\hline & Cause & Key factor \\
\hline 1 & $\begin{array}{c}\text { Senior or midlevel manager don't pay enough } \\
\text { attention to safety }\end{array}$ & Management attention \\
\hline 2 & $\begin{array}{c}\text { Relevant system, regulation and plan incomplete or } \\
\text { impracticable }\end{array}$ & $\begin{array}{c}\text { Institution, standard and } \\
\text { plan }\end{array}$ \\
\hline 3 & Lack of safety check and meeting & Safety supervisor \\
\hline 4 & Impractical safety and healthy education & Safety education \\
\hline 5 & Lack of safety investment & Safety investment \\
\hline
\end{tabular}

Measure method of SMI. To measure the SMI of a group should take samples first. We use the stratified sampling. According to previous studies, the minimum sampling ratio should be $60 \%$ of the total at least. Considering about the possibility of invalid questionnaires and other special circumstances, we increased the sampling ratio to $70 \%$. The $70 \%$ of the whole group was stratified sampled according to the position (e.g. worker, middle manager, manager)[17-18]. Then we organized the related personnel in the sample to test. When take the tables back, we got rid of the invalid questionnaires first (e.g. blank or similar answer one), and keep valid tables. The valid 
tables was analyzed of validity and reliability according to the principle of statistics [19-20]. After the reliability and validity of the data reached the standard, the data were summarized and statistical analyzed according to the value of each options. The average score of each subject and key factor was respectively work out as well as the average score of the total factors. In the end the SMI was worked out.

Conclusion of accident statistical index system of construction production safety

1) Pre-index. SBI and SMI are the accident statistical pre-indexes of construction production safety we built.

2) Post-index. The minor injury rate, serious injury rate and dearth rate should be included in the accident statistical index system by the research of construction enterprises in China and relevant expert consultation, the minor injury rate, serious injury rate and death rate should be included in the accident statistical index system of construction production safety. And the three indexes are used as the safety evaluation index in most of the construction enterprise. Although the death and serious injury do not always happen and the number of them make little sense of statistic to every project departments. They are possible from a statistical perspective and should be included in the index system. The enterprise should mainly use the pre-index while making the post-index subsidiary. And the safety level of the enterprise could de measured comprehensively.

In conclusion, the accident statistical index in China construction project, established by the author of this paper, is consisted of the following five indexes and including two pre-indexes and three post-indexes (see table 4).

Table 4 Summary of construction safety accident statistical indicator system

\begin{tabular}{|l|l|}
\hline Index type & Statistical index \\
\hline \multirow{2}{*}{ Pre-index } & SBI \\
\cline { 2 - 2 } & SMI \\
\hline \multirow{3}{*}{ Post-index } & Minor injury rate \\
\cline { 2 - 2 } & Serious injury rate \\
\cline { 2 - 2 } & Death rate \\
\hline
\end{tabular}

\section{Application of accident statistical index system of construction production safety}

An enterprise and one of its residential projects in Beijing are chosen as objects. The building area of the project is $80000 \mathrm{~m}^{2}$ and the structure type of it is frame-shear wall structure. It is in the process of structure construction. It has 250 workers and 30 project managers. The pre-index was focused researched on account of the death rate, serious injury rate and minor injury rate are easily counted and all of the three indexes are zero of this project.

\section{Application of SBI}

The project is in the process of structure construction while the lifting operation is the high risk one. The mainly purpose of this research is testing the feasibility of SBI measure method. So the SBI was mainly used to measure the lifting operation. From August to September is the observation time, and the SBI of the workers during that time was counted (table 5). Through averaged the four different kinds of SBI, the SBI of lifting operation in that project was worked out. It is $62.22 \%$ and means the SBI average value of the four kinds of key behavior. The key behavior whose SBI below the average value is the urgent problem of the enterprise. 
Table 5 Summary of safety behavior index of operating personnel in tower crane

\begin{tabular}{|c|c|c|c|}
\hline Category & $\begin{array}{c}\text { Number of } \\
\text { safe behavior }\end{array}$ & $\begin{array}{c}\text { Number of } \\
\text { unsafe behavior }\end{array}$ & SBI[\%] \\
\hline Individual protection & 19 & 16 & 54.29 \\
\hline Tool and equipment & 7 & 4 & 63.63 \\
\hline Personal location & 15 & 11 & 55.56 \\
\hline Operation program & 43 & 20 & 68.25 \\
\hline Total & 84 & 51 & 62.22 \\
\hline
\end{tabular}

\section{Application of SMI}

$70 \%$ of the staff was stratified sampled, and 197 people attended the SMI questionnaire survey. 191 questionnaires were taken back and got rid of 49 invalid questionnaires. There are 142 valid questionnaires. After the test of reliability and validity, we statistical analyzed the valid questionnaires and calculated the average value of each question. Then according to the five different kinds of key factors the average value of each factors was worked out (see table 6). The SMI of the project is 67.16 and the safety management of the enterprise exist many weakness that need to be improved.

Table 6 Summary of safety management index statistics

\begin{tabular}{|c|c|c|c|}
\hline Key factor & $\begin{array}{c}\text { Num } \\
\text { ber }\end{array}$ & Subjects & Score \\
\hline \multirow{4}{*}{$\begin{array}{l}\text { Manager } \\
\text { attention }\end{array}$} & 1 & Enterprise really care about the works safety & 3.21 \\
\hline & 2 & $\begin{array}{l}\text { Ask for the workers' opinions before formulate or amend } \\
\text { safety standard }\end{array}$ & 2.32 \\
\hline & 3 & Enough workers to make sure safety & 3.02 \\
\hline & \multicolumn{3}{|c|}{ Key factor score: 2.85} \\
\hline \multirow{6}{*}{$\begin{array}{l}\text { Institution ,st } \\
\text { andard and } \\
\text { plan }\end{array}$} & 4 & Some safety standards are out of date & 3.54 \\
\hline & 5 & Some safety standard are hardly observe & 3.42 \\
\hline & 6 & Some safety standard are not fully complied & 3.42 \\
\hline & 7 & $\begin{array}{l}\text { According to its actual risk, some work don't need "work } \\
\text { permit system" }\end{array}$ & 3.23 \\
\hline & 8 & I know the safety precautions of my job very well & 3.54 \\
\hline & \multicolumn{3}{|c|}{ Key factor score:3.43 } \\
\hline \multirow{5}{*}{$\begin{array}{l}\text { Safety } \\
\text { supervisor }\end{array}$} & 9 & Report to the supervisor after accident & 3.43 \\
\hline & 10 & $\begin{array}{c}\text { Someone will supervise us when we need to wear personal } \\
\text { protective equipment }\end{array}$ & 3.76 \\
\hline & 11 & $\begin{array}{c}\text { The safety patrol here can help improve safety and health of } \\
\text { workers }\end{array}$ & 3.73 \\
\hline & 12 & $\begin{array}{c}\text { The managers here will take measures after inspect or } \\
\text { industrial injury }\end{array}$ & 3.82 \\
\hline & \multicolumn{3}{|c|}{ Key factor score:3.69 } \\
\hline \multirow{3}{*}{$\begin{array}{l}\text { Safety } \\
\text { education }\end{array}$} & 13 & The company educate us carefully & 3.23 \\
\hline & 14 & The education of the company is useful & 3.36 \\
\hline & \multicolumn{3}{|c|}{ Key factor score:3.30 } \\
\hline \multirow{2}{*}{$\begin{array}{c}\text { Safety } \\
\text { investment }\end{array}$} & 15 & The company provides adequate resources to ensure the safety & 3.52 \\
\hline & \multicolumn{3}{|c|}{ Key factor score:3.52 } \\
\hline \multicolumn{3}{|c|}{ SMI(five-mark system):3.36 } & \\
\hline
\end{tabular}

\section{Conclusion}

1) The accident statistical "pre-index" of construction production safety is researched in the perspective of behavior causation of accident causation theory. And the range of accident 
statistical index is expanded;

2) Based on the existing accident statistical index, the accident statistical index of construction production safety was completed with two kinds of accident statistical pre-index of construction production safety which is SBI and SMI.

3) The application result shows that the accident statistical index could truly reflect the weakness of the enterprise production safety and reflect the state and level of the enterprise daily safety management dynamically.

\section{Acknowledgement}

This research was financially supported by the National Natural Science Foundation of China.

\section{References}

[1] The national implementation of production safety indicators control got significant progress in 2012 on http://www.chinasafety.gov.cn/newpage/Contents/Channel_20715/2013/0314/199070/content_1990 70.htm.

[2] Heinrich H, Industrial Accident Prevention, second ed., McGraw-Hill, New York, 1941, pp. 375-381.

[3] James R Phimister, Ulku Oktem, Paul R Kleindorfer, et al., Near-miss incident management in the chemical process industry, Risk Analysis, 23(3) 445-459.

[4] FU Gui, DENG Ning-jing, ZHANG Shu-liang, et al., Research on occupational safety and health performance index in US,UK and Australia and its reference to China, China Safety Science Journal, 20(7) 103-109.

[5] YANG Nai-lian, Study on improving statistics of work safety accidents in China, China Academy of Science and Technology, 7(7) 159-162.

[6] LV Hai-yan, Study on the Theory and Methods of Accident Statistics Analysis and Prediction, Beijing, Beijing Forestry University, 2004.

[7] WANG Lei, YAN Gang and CAI Hui-wang, Evaluation of building industry safety situation based on synthetic equivalent mortality method, China Safety Science Journal, 22(9) 10-15.

[8] Bird Jr Frank E, Management Guide to Loss Control, Atlanta, Institute Press, 1974, pp. 167-199.

[9] Engineering Quality Safety Supervision Division Minstry of Housing and Urban-Rural Development, Construction Accident Case Analysis, Beijing, China Architecture \& Building Press, 2009, pp. 8-135.

[10] CHEN Da-wei, TIAN Han-zhi, ZHANG Jiang-shi. Quantitative approach and demonstration study based safety behavior of construction accident prevention, China Safety Science Journal 20(7):96-102.

[11] GB6441-1986,Worker Casualty Classification Standards.

[12] CHENG Jie. The application of BBS in project safety management, Safety Health \& Environment, 9(7) 48-49.

[13] ZHANG Meng-chun,FANG Dong-ping. The cause of construction workers unsafe behavior cognition and management measures, China Civil Engineering Journal, 45(S2) 297-305.

[14] Heikki Laitinen, Markku Marjamaki, Keijo Paivarinta, The validity of the TR safety observation method on building construction, Accident Analysis and Prevention, 31(5): 463-472.

[15] Helen Lingard, Steve Rowlinson, Behavior-based safety management in Hong Kong's 
construction industry, Journal of Safety Research, 28(4) 243-256.

[16] ZHANG Jiang-shi, FU Gui, GUO Fang, et al., Safety climate measurement scale research,China Safety Science Journal, 19(6) 85-92.

[17] LU Bai, CHEN Pei, FU Gui, Research and design of safety climate questionnaire, Journal of Safety Science and Technology, 4(1), 47-50.

[18] TIAN Han-zhi. An Innovative and Applied Study Based on Behavior for Statistical Indexes in Construction Accidents, Beijing: Capital University of Economic \& Business, 2013.6.

[19] ZHAO Xian, FU Gui, Empirical study of enterprise safety climate evaluation, China Safety Science Journal, 20(9) 145-151.

[20] CHEN Yang, Measurement of Construction Enterprise Safety Atmosphere -Sampling Method and its Application, Beijing:, Tsinghua University, 2005. 